Polska Myśl Pedagogiczna

3 (2017), s. 13-29

doi: 10.4467/24504564PMP.16.001.6679

www.ejournals.eu/PMP

Katarzyna Olbrycht $t^{1}$

Uniwersytet Śląski w Katowicach

\title{
RUCH ZUCHOWY ALEKSANDRA KAMIŃSKIEGO. WYMIAR PEDAGOGICZNY
}

\section{Aleksander Kamiński’s Polish Cub Scout Movement. The Pedagogical Dimension}

Sum mary: The text presents the origins of the Polish cub scout movement, created within the Polish Scouting Association, and the role played by Aleksander Kamiński (an outstanding educator, scout instructor, author of important historical books on young scouts who were heroes of the 1944 Warsaw Uprising) in the emergence of this movement.

Through an analysis of Kamiński's texts concerning the building of the movement, the author argues that this movement constitutes a significant part of the Polish pedagogical heritage. Not only is this movement important in a historical sense, but also both in terms of the clarity of its objectives and in regards to the original methods and forms used to reach those objectives.

The Polish cub scout movement still uses the basic structures, methodological assumptions and organizational solutions developed by Kamiński. The presentation of the history of the movement in this article is limited to the initial period, the appearance of the concept itself and the period of its implementation according to Kamiński's presuppositions and under his direction, that is, until the years 1924-1958.

Keywords: Polish scouting movement, Polish cub scouts movement, Polish cub scouts, educational organization

Aleksander Kamiński (1903-1978) jest w polskiej pedagogice znany przede wszystkim jako wybitny pedagog społeczny, przedstawiciel środowiska łódzkiego, z którego wyrosła polska pedagogika społeczna. Kojarzony jest również

${ }^{1}$ Prof. zw. dr hab. Katarzyna Olbrycht - kierownik Zakładu Edukacji Kulturalnej w Instytucie Nauk o Edukacji na Wydziale Etnologii i Nauk o Edukacji w Cieszynie / Uniwersytet Śląski w Katowicach. Adres: Instytut Nauk o Edukacji UŚ, ul. Bielska 52, 43-400 Cieszyn; e-mail: k.olbrycht@onet.pl. 
z powstaniem i rozwojem Związku Harcerstwa Polskiego - przez wiele dziesięcioleci najbardziej znaczącej wychowawczej organizacji dzieci i młodzieży. Jednocześnie wszedł do polskiej kultury jako autor książek w niezrównany sposób opisujących walkę młodych Polaków, szczególnie harcerzy, z okupantem w czasie II wojny światowej, głównie podczas powstania warszawskiego 1944 roku. Kamienie na szaniec oraz „Zośka” $i$ „Parasol” stały się nie tylko elementem kanonu lektur szkolnych, ale także książkami, które wielokrotnie wznawiane utrwaliły portret i etos młodych Polaków związanych z polskim ruchem oporu, Szarymi Szeregami i Armią Krajową.

Życie i dorobek Aleksandra Kamińskiego zostały już przedstawione w wielu publikacjach skupiających się na całej tej niezwykłej biografii bądź jej fragmentach oraz na wyjątkowej osobowości jej bohatera. Wśród licznych opracowań szczególne wrażenie pozostawiają te, w których autorzy przyznają się do ogromnej roli, jaką w ich życiu odegrała znajomość czy przyjaźń z Kamińskim (Wincenty Okoń, Barbara Wachowicz), do podziwu dla jego postaw i życia (Andrzej Janowski).

Piszący o Kamińskim autorzy podkreślają, iż wniósł on ogromny wkład w wychowanie młodych pokoleń, a także pedagogów nie tylko przez swoje teksty i działania, ale dzięki jednoznacznej, czytelnej postawie ludzkiej, patriotycznej, harcerskiej i na tym gruncie - pedagogicznej.

Nie wszystkie jego działania i prace są równie znane, a tym samym nie wszystkie są tak cenione i wykorzystywane przez współczesnych pedagogów, jak na to zasługują. Jednym $\mathrm{z}$ takich mniej znanych obszarów jest stworzenie $\mathrm{ruchu} \mathrm{zucho-}$ w e go, w którym wychowało się (i nadal wychowuje, choć w nieco już zmienionych formach) wiele tysięcy dzieci - zuchów i instruktorów zuchmistrzów.

\section{Ruch zuchowy}

Ruch zuchowy to pierwszy, podstawowy poziom ruchu harcerskiego, w założeniu przeznaczony dla dzieci w wieku 8-11 lat (dziś 6-10 lat). W ciągu swojego istnienia i rozwoju ruch ten stał się nie tylko masową wychowawczą organizacją dzieci, stanowiącą jednocześnie przygotowanie do uczestnictwa w ruchu harcerskim, ale także znaczącą częścią polskiego dorobku pedagogicznego.

Jak cały Związek Harcerstwa Polskiego, ruch zuchowy przechodził w swej historii dramatyczne momenty wyznaczone losami Polski.

Kiedy brytyjski generał lord Robert Baden-Powell stworzył w 1907 roku skauting jako organizację wychowawczą dla chłopców, oparł jej program na ideach społeczno-religijnych, patriotycznych i zasadach militarnych, wprowadzanych poprzez grę i to ona właśnie miała się stać znakiem rozpoznawczym tej organizacji. Napisany przez Baden-Powella podręcznik skautingu Skauting for Boys, będący jednocześnie książką adresowaną do młodych chłopców - potencjalnych członków ruchu - szybko stał się znany na świecie. Trafił również do Polski, gdzie 
został przetłumaczony w 1911 roku we Lwowie przez Andrzeja Małkowskiego. Idea skautingu trafiła $\mathrm{w}$ Polsce na podatny grunt tradycji organizacji młodzieżowych o ideałach niepodległościowych i samokształceniowych, samowychowawczych i religijnych (Zarzewie, Eleusis, Sokół), co sprawiło, że bardzo szybko zaczęły powstawać organizacje skautowskie. Po ukazaniu się w 1912 roku we Lwowie kolejnego podręcznika skautingu autorstwa Mieczysława Schreibera i Eugeniusza Piaseckiego Harce młodzieży polskiej, ustaliło się polskie nazewnictwo struktur ruchu: harcerz, zastęp, drużyna, hufiec, chorągiew (znamienne jest sięgnięcie w tym celu do języka rycerskiego). Od początku polskie harcerstwo obejmuje zarówno ruch męski, jak i ruch żeński (zainicjowany w 1912 roku przez Olgę Drahonowską-Małkowską, żonę Andrzeja Małkowskiego). Licznie powstające organizacje, najpierw na terenie Królestwa Polskiego, w 1916 roku łączą się w Związek Harcerstwa Polskiego, który następnie - po zjeździe w Lublinie w 1918 roku - staje się organizacją zrzeszającą harcerzy ze wszystkich ziem polskich oprócz środowiska lwowskiego. Środowisko to dołącza do ZHP na zjeździe w 1919 roku. Wtedy też na przewodniczącego związku zostaje wybrany Tadeusz Strumiłło.

Ze względu na ogromną popularność skautingu także wśród młodszych chłopców (8-11 lat) Baden-Powell już w roku 1912 rozpoczął opracowywanie programu skautingu dla tej grupy, nazywając ją „wilczętami”. Od 1912 do 1916 roku przygotowywał materiały do pracy z nimi, publikując dla nich gawędy, ostatecznie zebrane $\mathrm{w}$ jednym tomiku, stanowiącym od 1916 roku formę podręcznika ruchu „wilcząt”. Podstawą była tu jeszcze nie gra i nie ćwiczenia skautów, ale zabawa „w coś”. Główną tematyką tych zabaw było życie (najczęściej zwierząt) w egzotycznej dżungli, znane angielskim chłopcom wzrastającym $\mathrm{w}$ atmosferze angielskich doświadczeń kolonialnych, oraz życie Indian. Baden-Powell opracował główne formy i struktury ruchu „wilcząt”, takie jak: praca w gromadzie podzielonej na szóstki kierowane przez szóstkowych, zdobywanie sprawności i gwiazdek, przyrzekanie przestrzegania specjalnego Prawa, znaki.

W Polsce również bardzo szybko zaczęto podejmować próby formułowania koncepcji programu skautingu dla młodszej grupy wiekowej (8-12 lat). Dopiero jednak po ukazaniu się przetłumaczonych przez Tadeusza Strumiłłę Wilcząt Baden-Powella (w 1922 - cz. 1 i w 1928 roku - cz. 2), przedstawiających metodykę pracy z młodymi skautami-,,wilczętami”, rozpoczyna się rozwój polskiego ruchu "gromad wilczęcych" działających przy drużynach harcerskich. W myśl propozycji jednego z pierwszych przewodniczących ZHP ks. Jana Pawła Mauersbergera „wilczęta” w Polsce zaczęły być nazywane „zuchami”. Wcześniej nazwą "zuchy” posługiwała się Jadwiga Zienkiewiczówna, zakładając organizację małych harcerek, daleką jednak metodycznie od harcerstwa. Początkowo polski ruch chłopców wzorował się na angielskich „wilczętach”. Podobnie próbowano organizować ruch „wilcząt” dla dziewczynek, ale kiedy okazało się, że nie zyskuje

\footnotetext{
2 Aleksander Kamiński, Krąg Rady (Katowice: nakładem „Na tropie” 1937), 15-16.
} 
on popularności w tej grupie, nawet jeśli jest dostosowywany do jej zainteresowań (tworzono organizacje „sarenek”, „krasnoludków”), żeńskie środowisko harcerskie, z inicjatywy nauczycielki i instruktorki harcerskiej Jadwigi Zwolakowskiej, w 1926 roku stworzyło specjalną gałąź ruchu zuchowego dla dziewczynek z odrębnymi sprawnościami, regulaminem gwiazdek i tematami zabaw. Dwa lata później, w 1928 roku, J. Zwolakowska została pierwszą komendantką Wydziału Zuchów Głównej Kwatery Harcerek. Opracowała też pierwsze zbiory zabaw, piosenek i scenariuszy zbiórek dla zuchów-dziewczynek.

W 1924 roku Aleksander Kamiński, zafascynowany postacią i programem Andrzeja Małkowskiego, mający już duże doświadczenie harcerskie, zaczyna się interesować polskimi „wilczętami”. W 1931 roku ostatecznie zdecydował się na dopracowanie charakteru ruchu zuchowego, nadając mu polską specyfikę wynikającą z potrzeb wychowawczych, które uważa za szczególnie ważne i pilne. Powodem tej decyzji było stwierdzenie na podstawie obserwacji sztuczności tematyki i charakteru „wilcząt” przeniesionych w dosłownej formie z terenu doświadczeń i zainteresowań chłopców angielskich do Polski, a także sceptyczna postawa nauczycieli i rodziców do tego typu zajęć. Najważniejszą metodą pracy z zuchami stała się - jak w angielskich „wilczętach” - zabawa „w coś”, stopniowo określana zabawą tematyczną, ale nawiązująca do polskich tradycji, historii, zawodów i zajęć.

\section{Aleksander Kamiński - twórca ruchu zuchowego}

Droga do stworzenia ruchu zuchowego prowadziła Kamińskiego od wstąpienia w 1918 roku do drużyny harcerskiej w Humaniu (dziś Ukraina), gdzie rzuciły go losy rodzinne, do pełnienia tam funkcji zastępowego, przybocznego, wreszcie drużynowego. Do wiosny roku 1920 była to bardzo aktywna działalność prowadzona oficjalnie. Od maja tegoż roku, kiedy represje bolszewickie wobec Polaków objęły także bardzo dynamiczne na tym terenie środowisko skautowe, Kamiński rozpoczął wraz z całym Gniazdem Humańskim (skupiającym drużyny harcerskie z terenu Humania) działalność harcerską w konspiracji. Istotnymi elementami życiowej drogi Kamińskiego były: doświadczenie trudu życia w warunkach wojennych (I wojny światowej), wczesnego rozstania z matką oraz konieczność podjęcia w wieku 12 lat pracy zarobkowej (jako goniec), pobyt w placówkach opiekuńczych dla sierot (a później w Polsce praktyki w roli wychowawcy w takich placówkach), działalność harcerska w sytuacji rosnącego zagrożenia. W 1921 roku osiemnastoletniemu Kamińskiemu udaje się opuścić Humań i dostać do Polski. Z pomocą przyjaciela Oskara Żawrockiego, instruktora harcerskiego, który wyjechał z Humania do Polski wcześniej, otrzymuje pracę pomocnika wychowawcy i możliwość zamieszkania w bursie dla chłopców w Pruszkowie. Podejmuje naukę w gimnazjum w Warszawie i od razu aktywnie 
włącza się w działalność harcerską w Pruszkowie, a także przechodzi kolejne kursy instruktorskie. Po zdanej w 1922 roku maturze rozpoczyna studia historyczne na Uniwersytecie Warszawskim, wybierając jako główne dziedziny zainteresowań historię średniowieczną i archeologię. Jego zaangażowanie harcerskie w tym czasie obejmuje coraz bardziej odpowiedzialne funkcje i działania. Kamiński zostaje powołany do prowadzenia hufca pruszkowskiego skupiającego drużyny z kilku okolicznych miejscowości. Rozpoznany w swoich talentach wychowawczych i organizacyjnych jest coraz bardziej ceniony jako instruktor kształcący innych instruktorów.

W roku 1924 pojawiają się pierwsze wzmianki o zainteresowaniu Kamińskiego najmłodszą grupą skautową - „wilczętami”3. Stopniowo ta grupa stanie się dla niego środowiskiem szczególnej aktywności, twórczego poszukiwania i sprawdzania rozwiązań modyfikujących formę angielskich „wilcząt”. Kamiński nie zmienia założeń przyjętych w skautingu i angielskich „wilczętach”, ale interpretuje je i przekłada na treści odpowiadające polskiej sytuacji społecznej, politycznej i kulturowej. Po latach krystalizowania się nowego programu w 1934 roku w Kręgu Rady pisze:

Pozostaliśmy - zuchowy ruch chłopięcy - pols k i m w ilczęct we m. Zatrzymaliśmy całkowicie „cel i ducha”. Zatrzymaliśmy całkowicie system wychowania przez zabawę, pojętą jako zabawę „w coś”. Nie zmieniliśmy prawie zupełnie form organizacyjnych [...]. Przede wszystkim zaś zatrzymaliśmy całkowicie przepojenie naszego ruchu zuchowego - wzorem wilczęctwa - duchem ideałów i metody skautowej. [...] Wilczęctwo to dopasowaliśmy, co określić należy jako ogromny dorobek, do psychiki chłopca polskiego, do zainteresowań naszego społeczeństwa i do potrzeb naszego kraju4 .

W tym miejscu trzeba zauważyć charakterystyczny rys myślenia Aleksandra Kamińskiego nie tylko o walorach organizacji dziecięcych i młodzieżowych, ale także o ich polskiej specyfice, $\mathrm{z}$ ich niezastępowalnym potencjałem i możliwościami. Warto przytoczyć fragment jego tekstu:

Co uczyniliśmy ze skautingiem angielskim, aby go dopasować do właściwości naszej młodzieży? Po głębiliśm y go! Jest w naturze Słowian, a Polaków w szczególności, że życie traktują serio. Prostota i radosna uciecha nie wystarczają nam [...] do dostatecznego traktowania zjawisk życia. Zasadniczość i głębsza racja muszą być motywem naszych czynów. Skauting angielski jest pod wybitną przewagą zabawy. Nasze harcerstwo, pragnie za pomocą d obr ze zorganizowanej zabawy, st a ra n n i e przygotować młodzież do odegrania roli w życiu społecznym. Nasze gawędy są raczej poważnymi rozważaniami samowychowawczemi niż niefrasobliwymi opowiadaniami przygód ${ }^{5}$.

${ }^{3}$ Andrzej Janowski, Być dzielnym i umieć się różnić. Szkice o Aleksandrze Kamińskim (Warszawa: Wydawnictwo Naukowe PWN 1992), 57.

${ }^{4}$ Kamiński, Krąg Rady, 20.

${ }^{5}$ Tamże, 13. 
(Wiele lat później, już jako pedagog społeczny uprawiający pedagogikę naukowo, Kamiński rozwinie teoretycznie swoje poglądy na temat wychowawczej wartości organizacji młodzieżowych i ich polskich tradycji). W roku $1929 \mathrm{w}$ czasopiśmie harcerskim „Na tropie” Kamiński zaczyna publikować w odcinkach przygody Antka Cwaniaka. Ich bohaterem jest piętnastoletni harcerz Antek Cwankiewicz, który otrzymuje w drużynie zadanie zorganizowania gromady zuchów. Czytelnik poznaje w barwnym opowiadaniu drogę powstawania gromady, począwszy od docierania do miejscowych chłopców, pomysłów ich wciągania do gromady, trudności z wymyślaniem ciekawych zbiórek i zadań, przykładów zabaw i gier aż do prób pozwalających przyjąć chłopców do gromady zuchowej jako prawdziwych zuchów. Pomysły, które przypisał swojemu bohaterowi, Kamiński sprawdza w czasie kursu drużynowych zuchowych w lecie 1931 roku. W tym samym roku w październiku Naczelnik Harcerzy na podstawie opinii specjalnej komisji przy Głównej Kwaterze Harcerzy zatwierdził i przyjął formalnym rozkazem Regulaminy Zuchowe przekształcające chłopięce gromady "wilcząt” w gromady zuchowe chłopców ${ }^{6}$. W Głównej Kwaterze Harcerzy powstaje Wydział Zuchowy, którego komendantem zostaje Aleksander Kamiński.

Antek Cwaniak - opowiadanie w formie książki o przygodach młodego bohatera rozpoczynającego przygodę bycia wodzem gromady zuchowej wychodzi w 1932 roku i jest pierwszym z trzech tomów trylogii zuchowej. Kolejnym jest Ksiażka Wodza Zuchów (1933), a ostatnim - Krag Rady (1934/1935)7. Wszystkie trzy książki tego cyklu adresowane są do wodzów zuchowych gromad, instruktorów zuchowych, opiekunów i przyjaciół ruchu zuchowego. Napisane żywym językiem, dalekim od teoretyzowania, a już szczególnie dydaktyzowania i moralizowania, są formą podręcznika, a jednocześnie dokumentem ukazującym metodę działania Kamińskiego. Składają się na nią: odwoływanie się do przykładów, pomoc w trudnościach, podsuwanie atrakcyjnych pomysłów, szacunek dla czytelnika niezależnie od wieku, stopnia i funkcji, motywowanie do twórczej aktywności w działaniu, ale z jasnym określaniem reguł i wymagań. Chociaż pisane ponad 80 lat temu, można je z powodzeniem uznać za lekturę inspirującą, motywującą, praktycznie przydatną i poznawczo cenną dla każdego pedagoga, także współczesnego. Zamysł zuchowej trylogii, która miała być uzupełnieniem kursów nastawionych na uczenie „zuchowania” w praktyce, najlepiej wyjaśniał sam autor. W Przedmowie do Kręgu Rady napisał:

Antek Cwaniak, który zapoczątkował akcję zuchową - został pomyślany jako elementarne wprowadzenie w treść i metodę zabaw i zbiórek zuchowych. Potem przyszła Książka Wodza Zuchów - będąca zbiorem wielu setek ćwiczeń i zabaw. Antek mówił, ja k się bawić, Książka doradzała, w co się bawić.

6 Tamże, 24.

7 Barbara Wachowicz, Kamyk na szańcu. Gawęda o druhu Aleksandrze Kamińskim w stulecie urodzin (Warszawa: Oficyna Wydawnicza Rytm 2002), 114. 
Teraz, gdy pierwsze potrzeby zostały już zaspokojone, jest czas zastanowić się nad tym, po co właściwie są te zuchowe zabawy, oraz zdać sobie sprawę, czego się po zabawach zuchowych spodziewać nalė̇̇ ${ }^{8}$.

Polskie zuchy (chłopcy w wieku 8-11 lat) miały, w założeniach Kamińskiego, wychowywać się przez wspólną zabawę razem z włączonym w nią, ale i podsuwającym kolejne pomysły, starszym towarzyszem zabawy - wodzem gromady lub (już po kursach i innych formach przygotowania) instruktorem zuchowym. Wszystkie formy pracy z zuchami (sprawności - nawiązujące do różnych zawodów, postaci i grup historycznych, specjalnych umiejętności i zadań, gwiazdki, obrzędy, majsterkowanie, zawody, piosenki i pląsy, teatrzyki, kominki, zbiórki $\mathrm{w}$ pomieszczeniach, ale przede wszystkim w terenie i w kontakcie z przyrodą) miały nawiązywać do zainteresowań chłopców w tym wieku, do ich naturalnych zabaw i form spędzania czasu. Kamiński podkreślał wielokrotnie, że zuchowanie nie powinno metodycznie być tym samym co harcerstwo, wprowadzać tych samych gier, ćwiczeń, wymagań, ponieważ możliwości młodszych chłopców są inne, a poza tym powinni oni mieć przed sobą nowy, trudniejszy etap i cel - zostanie harcerzem.

Zuchowanie miało wspomagać główne środowiska wychowawcze - dom, szkołę i Kościół, ale nie zastępować ani nie powielać ich działań. W koncepcji Kamińskiego wodzami zuchów i instruktorami zuchowymi mogli być także nauczyciele, pod warunkiem że byliby zdolni do zmiany roli: do pracy metodami zuchowymi, a nie szkolnymi, do wchodzenia w relacje z zuchami bez traktowania ich jak uczniów. Kamiński dostrzegł, że bardzo ważny dla rozwoju dziecka wzajemny wpływ rówieśników, szczególnie w czasie wolnym i w czasie wspólnych spontanicznych zabaw z kolegami, w praktyce pozostaje poza zainteresowaniem pedagogów. Tym samym gubi się wychowawczy potencjał tych kontaktów i wpływów. Zuchy miały wypełnić tę lukę i wyzwolić niewykorzystane dotąd możliwości rozwoju przez ciekawą zabawę z rówieśnikami, zabawę uruchamiającą motywację do doskonalenia swoich umiejętności, sprawności, zachowań, a tą drogą - kształcenia postaw. Ruch zuchowy miał mieć wyraźną specyfikę wychowawczą opartą na kształceniu w chłopcach dzielności jako umiejętności pokonywania lęków i słabości. Tak jak w harcerstwie i w jego pierwowzorze (skautingu), w ruchu zuchowym miało obowiązywać braterstwo między harcerzem starszym i młodszym, między harcerzami rówieśnikami, między zuchem i wodzem oraz wśród samych zuchów. Pozostał tak jak w skautingu także wewnętrzny kodeks moralny przyjmowany dobrowolnym Przyrzeczeniem, w ruchu zuchowym - Obietnicą, opisany Prawem skautowym, tu - Prawem Zucha. $\mathrm{W}$ jego treści zostały uwzględnione powinności pomagające walczyć z cechami najtrudniejszymi dla każdego człowieka, ale i dla polskiej kultury i społeczeństwa

\footnotetext{
${ }^{8}$ Kamiński, Krąg Rady, 5.
} 
(z brakiem karności, zdyscyplinowania, troski o dobro wspólne, odpowiedzialności obywatelskiej, ze słabością charakteru). Rotę Prawa Zucha Kamiński sformułował, współpracując z zuchmistrzynią J. Zwolakowską, by podstawowe ideały zuchowania były wspólne dla chłopców i dziewczynek.

Pierwsze (później kilkakrotnie zmieniane) Prawo Zucha brzmiało:

1. Zuch kocha Boga i Polskę.

2. Zuch jest dzielny.

3. Wszystkim jest $\mathrm{z}$ zuchem dobrze.

4. Zuch stara się być coraz lepszy.

W centrum działań wychowujących przez zabawę do realizacji ideałów zawartych w Prawie Zucha Kamiński umieścił, jak wspomniano, dzielność. Pisał:

Wychowanie w dzielności - jest naczelnym celem ruchu zuchowego. Zapełnia się w ten sposób dział wychowania, pozostawiany dotychczas samemu sobie, pozbawiony życzliwego oka i życzliwej rady wychowawcy. [...] Dzielność, do której trafia się i którą rozwija się poprzez zainteresowania chłopców - oto istota ruchu zuchowego'.

Dzielność miała służyć temu, by zuch chciał i umiał być chłopcem (dzieckiem), z którym jest dobrze innym.

Ruch zuchowy miał być zabawą kształcącą dziecięce charaktery przez atrakcyjne dla nich formy zajęć i zadania i na tej drodze kształtującą pozytywne postawy ludzkie i obywatelskie. W drugim tomie trylogii zuchowej, stanowiącym zbiór ćwiczeń, zabaw, gier, pomysłów zadań, Kamiński napisał:

Czym jest zuchowa gałąź harcerstwa? Jest to zabawa dzielnych chłopców i dziewcząt. Zabawa trwająca całe dnie, tygodnie, miesiące i lata. Zabawa - zuchów, którzy są odważni w grach i odważni w mówieniu prawdy, którzy są zwinni i zręczni, mają bystre oczy, bystre palce i bystre głowy. Zabawa w majsterklepków, potrafiących wykonać własnoręcznie wiele rzeczy, zabawa w „krasnoludków”, ciągle szukających sposobności do robienia przyjacielskich usług, zabawa w „leśnych duchów” podpatrujących życie zwierząt i roślin. Zabawa wymagająca karności i współdziałania, opanowania i poświęcenia. Zabawa prowadzona przez samych chłopców i dziewczęta. Radosna, porywająca zabawa, w której nabiera się dobrych przyzwyczajeń! Oto czym jest ruch zuchowy! $!^{10}$

Zgodnie z zamysłem Kamińskiego najwięcej o koncepcji „zuchowania” można się dowiedzieć $\mathrm{z}$ ostatniego tomu zuchowej trylogii - Kręgu Rady. Ta niewielka rozmiarami książka zawiera ogromne bogactwo treści, przedstawionych i uporządkowanych tak, by łatwo było je zrozumieć i z nich korzystać. Obejmuje

\footnotetext{
9 Tamże, 43.

${ }_{10}$ Aleksander Kamiński, Książka drużynowego zuchów, wyd. V (Warszawa: Wydawnictwo Ministerstwa Obrony Narodowej 1957), 12-13.
} 
krótką historię skautingu, harcerstwa, ruchu zuchowego, istotę skautingu i harcerstwa, specyfikę ruchu zuchowego i omówienie różnic między pracą z zuchami i z harcerzami, miejsce ruchu zuchowego w harcerstwie i światowym skautingu, wreszcie - metodę zuchową jako metodę do wykorzystania w szkole. Duży fragment został poświęcony cechom dziecka w wieku zuchowym na tle ogólnej charakterystyki rozwoju fizycznego i psychicznego człowieka. Określone możliwości i właściwości rozwojowe poparte zostały od razu przykładami odpowiednich zabaw, ćwiczeń, działań. Wreszcie bardzo interesująco - gdyż wnikliwie a jednocześnie bardzo praktycznie, omówione zostały trudności wychowawcze i najczęstsze kłopotliwe sytuacje występujące w pracy z chłopcami - zuchami. Także tu Kamiński nie tylko je opisuje i wyjaśnia ich przyczyny, ale zastrzegając, że nie są to „uniwersalne recepty”, podsuwa także konkretne rozwiązania, sposoby radzenia sobie w taki sposób, by pomagało to i instruktorowi, i przede wszystkim dziecku sprawiającemu trudności. Przytoczmy przykładowe tytuły podrozdziałów: „Chłopiec bijący się”, „Chłopiec nieposłuszny”, „Niedorajda”, „Chłopiec upośledzony fizycznie". Autor jasnym, zrozumiałym językiem omawia problemy i trudności wychowawcze, odwołując się do współczesnych mu badań znanych psychologów (Charlotte Bühler, Édouarda Claparede’a, Mieczysława Kreutza, Stefana Szumana), do doświadczeń wybitnych pedagogów (na przykład Marii Montessori, Ludwiki Jeleńskiej, Janusza Korczaka).

$\mathrm{Z}$ perspektywy myślenia pedagogicznego znamienne jest to, że Kamiński omawianie trudności w działaniach $\mathrm{z}$ chłopcami rozpoczyna od przeanalizowania zachowań i postaw nie dzieci, ale wodza czy instruktora. W tytule jednego z podrozdziałów Kręgu Rady znajdujemy zalecenie: „usuńmy trudności prowokowane przez samego instruktora"1 ${ }^{11}$. Autor pisze:

Jeżeli tak jest w rzeczywistości, że nie możesz sobie poradzić z opanowaniem dwudziestu zuchów - proś natychmiast o zwolnienie ze stanowiska wodza gromady, gdyż musisz nie mieć w sobie nawet małej ilości pierwiastka wodzowskiego, nie promieniujesz, widać, zupełnie autorytetem - skoro chłopcy tego nie odczuwają. Odejdź! ${ }^{12}$

W innym miejscu znajdujemy zestawienie przyczyn trudności tkwiących po stronie instruktora: „Wydaje rozkazy zbyt trudne do spełnienia. Nie umie objaśnić prawideł zabawy. Nie umie zorganizować zabawy. Jest nieenergiczny. Nie umie wzbudzić zaufania. Nie umie zaimponować niekarnemu chłopcu”13. Nie oznacza to jednak, że dla Kamińskiego najważniejsze były umiejętności metodyczno-techniczne i organizacyjne instruktorów zuchowych. W tymże Kręgu Rady czytamy:

\footnotetext{
11 Kamiński, Krąg Rady, 137.

12 Tamże, 139.

13 Tamże, 149 (przypis).
} 
Instynkt wodzowski - to bardzo wiele, to punkt wyjścia na dobrego instruktora. Bez tego - nie można zabrać się do prowadzenia zuchów. Jeden tylko warunek musi być spełniony: że instynkt wodzowski będzie reprezentował wysoką m or a le człowieka. [...] Instruktorzy zuchowi! [...] Musicie sobie w pełni zdawać sprawę, że tym, co decyduje o waszej wartości - jest morale! Nie to jest najważniejsze, czy lepiej czy gorzej poprowadzicie jakiś kurs, nie to stanowi o Waszej roli w życiu harcerskim, że jesteście dobrymi organizatorami pracy! Nie to - że potworzycie mnóstwo gromad! Nie to że będziecie pełnymi zuchowej wiedzy i doskonale radzić sobie potraficie $\mathrm{z}$ dziećmi. Nie to, nie to! [...] Póki czyny wasze bazowane są na waszej morale - nic nimi nie zachwieje. Gdy morale się zarysuje - wszystko może zawalić się w gruzy ${ }^{14}$.

Wśród wymienionych przez Kamińskiego wymagań wobec wodza zuchów pojawia się też miłość do wychowanków. W Kręgu Rady pisze do czytelników przyszłej kadry zuchowej:

Wychowanie - niepoparte miłością do wychowanka jest bez wartości. Dziecko czy młodzieniec ma pod tym względem niezawodną intuicję. Potrafi nieomylnie wyczuć miłość, obojętność lub niechęć. Biada wychowawcy, który przyszedł do dzieci $\mathrm{z}$ chłodnym sercem ${ }^{15}$.

Bycie dobrym wodzem zuchów i instruktorem zuchowym wymaga środowiska, które pomaga stale rozbudowywać pomysły, oraz atmosferę przyjaźni i zrozumienia, wspólnego „klimatu moralnego”. Dlatego Kamiński podkreśla rolę gromad wodzowskich i traktuje je jako warunek dobrej pracy z zuchami. Mają one, podobnie jak gromady zuchowe, być wspólnotami przyjaźni ${ }^{16}$.

\section{Kamiński - realizator idei ruchu zuchowego}

Kamiński opracowuje system wychowawczy ruchu zuchowego, ale jednocześnie wprowadza go w życie, sprawdza, udoskonala, kształci instruktorów do jego realizacji.

Wiele lat później, w 1961 roku, w liście do Jacka Kuronia pisze:

Pragnę wyrazić myśl zasadniczą: dobry system i dobra metoda to oczywiście doniosłe narzędzie wychowawcze, ale uruchamia je żywy człowiek, wychowawca, instruktor. Wychowawcy nie przejmującemu się swym zadaniem niewiele dopomoże dobry system, natomiast wychowawca $\mathrm{z}$ zapałem będzie miał dobre osiągnięcia nawet operując kiepską metodą ${ }^{17}$.

\footnotetext{
14 Tamże, 178, 180.

15 Tamże, 184.

16 Tamże, 233.

17 Janowski, Być dzielnym, 216.
} 
Ruch zuchowy w kształcie stworzonym przez Kamińskiego zyskał bardzo szybko wielu członków. Ich liczba od roku 1931, kiedy wynosiła 6686 chłopców, wzrosła już w roku 1933 do $25185^{18}$.

W 1933 roku zostaje powołana do życia pierwsza szkoła „wodzów zuchowych" (Szkoła Instruktorów Zuchowych). Jej uruchomienie w Nierodzimiu koło Skoczowa inicjuje i finansuje ówczesny wojewoda śląski Michał Grażyński, od 1931 roku pełniący funkcję przewodniczącego Związku Harcerstwa Polskiego $^{19}$. Szkołą Instruktorów Zuchowych kieruje od początku jej istnienia do roku 1937 Aleksander Kamiński. W szkole odbywają się kursy instruktorów zuchowych, a jednocześnie przez 10 miesięcy w roku 6-tygodniowe kolonie zuchowe dla dzieci z najbiedniejszych robotniczych rodzin Śląska. Kolonie te pozwalają sprawdzać $\mathrm{w}$ praktyce system pracy z zuchami. W przeprowadzonych w Szkole Instruktorów Zuchowych do 1937 roku 90 kursach instruktorskich wzięło udział 1612 harcerek i harcerzy. Koloniami objęto 1960 dzieci $^{20}$. W roku 1937 Kamiński obejmuje kierownictwo Ośrodka Harcerskiego w Górkach Wielkich, gdzie uruchomiona została także Szkoła Instruktorów Zuchowych, kontynuująca działalność Szkoły w Nierodzimiu. Ostatnie kursy w ośrodku w Górkach odbywały się jeszcze w sierpniu 1939 roku.

Doświadczenia zdobyte w pracy z zuchami zaowocowały prowadzeniem przez Kamińskiego od roku 1935 eksperymentu nad wprowadzaniem metody harcerskiej do pracy szkoły (od klasy III szkoły podstawowej). To ten eksperyment (tak zwany eksperyment mikołowski, prowadzony w Mikołowie na Śląsku) zapoczątkował w polskiej praktyce szkolnej pracę małymi grupami („gromadkami” wzorowanymi na zuchowych szóstkach), odwołującą się do zainteresowań uczniów (przez realizowanie części zadań metodą zdobywania sprawności w czasie zajęć lekcyjnych i pozalekcyjnych) ${ }^{21}$.

Rozwój ruchu zuchowego przerwał wybuch wojny we wrześniu 1939 roku. Aleksander Kamiński już w październiku 1939 roku wstępuje do Służby Zwycięstwu Polski, gdzie dostaje zadanie zorganizowania pisma „informującego o sytuacji wojennej, politycznej, społecznej, gospodarczej kraju i świata”22. Kamiński

18 Wachowicz, Kamyk, 118.

19 Michał Grażyński już w 1931 roku wspiera rozbudowę stanicy harcerstwa śląskiego na działce odkupionej od Tadeusza Kossaka - ojca Zofii Kossak - na Szkołę Instruktorską Harcerstwa Żeńskiego na Buczu. Z czasem w jej sąsiedztwie powstanie piękny Ośrodek Harcerski w Górkach Wielkich k. Ustronia, prowadzony przez Aleksandra Kamińskiego do wybuchu wojny w 1939 roku. Por. tamże, 139.

20 Za: tamże, 122.

${ }^{21}$ O eksperymencie mikołowskim Kamińskiego pisze Bogusław Śliwerski w poświęconym pedagogice Kamińskiego rozdziale podręcznika Współczesne teorie i nurty wychowania (Kraków: Oficyna Wydawnicza „Impuls” 1998), 77-78; ten fragment pracy Kamińskiego wspomina także Wincenty Okoń w rozdziale „Aleksander Kamiński - pedagog praktycznego humanizmu”, w: tegoż, Wizerunki sławnych pedagogów polskich (Warszawa: Wydawnictwa Szkolne i Pedagogiczne 1993), 187.

22 Tamże, 212. 
zostaje redaktorem tygodnika konspiracyjnego „Biuletyn Informacyjny”, potem także szefem Biura Informacji i Propagandy Okręgu Warszawskiego Związku Walki Zbrojnej, wreszcie inicjatorem i organizatorem Organizacji Małego Sabotażu „Wawer” w Warszawie. Jeden z okręgów „Wawra” powierza harcerzom. Doświadczenie działania w okupowanej Warszawie i udział w powstaniu warszawskim staną się podstawą opisujących ten czas i jego bohaterów książek Wielka gra, Kamienie na szaniec oraz „Zośka” i „Parasol”.

Wojna przerwała rozwój ruchu zuchowego. Zginęło wielu instruktorów budujących wraz z Kamińskim ten ruch. Kamiński wymienia z imienia i nazwiska kilkanaścioro z nich we Wstępie do pierwszego powojennego wydania Antka Cwaniaka, które ukazało się w 1947 roku. Czytamy tam poruszające słowa pokazujące, jak ważne były zuchy dla ich twórcy.

Ludzie ci swym zdumiewającym zapałem i ofiarną pracą stworzyli i utrwalili ruch zuchowy, czyniąc zeń wyjątkowo żywotną gałąź Harcerstwa. I ci sami ludzie - gdy nadszedł czas wielkiej próby, wspaniale zdali swój egzamin w Szarych Szeregach - zakonspirowanego Harcerstwa. [...] Gromady zuchowe po pięciu i pół latach zupełnej przerwy w pracy zostały jakby z korzeniami wyrwane. Środowiska harcerskie przechowały w konspiracji tradycje pracy, po organizacji zuchowej nie zostało - bo nie mogło zostać - dosłownie nic: małe dzieci nie nadają się do przechowywania tradycji nieodświeżanej nieustanną czynnością ${ }^{23}$.

Autor w tym samym tekście wspomina swoje zaskoczenie i wzruszenie, kiedy już w kwietniu 1945 roku ktoś odnalazł go i zaprosił na kurs zuchowy i zuchowe święto. Pisze: „Skądś zjawili się nowi ludzie, którzy z zapałem, energią i oddaniem godnym »szaleńców zuchowych" z lat 1929-1939 organizują nowe drużyny"24. W tym samym roku 1945 w Londynie wychodzi trzecie wydanie Antka Cwaniaka. W 1947 udaje się opublikować tę podstawową dla instruktorów zuchowych książkę w Katowicach. Pozostałe dwa tomy zuchowej trylogii ukazują się w tymże roku odbite w Dziale Grafiki Zakładu Salezjańskiego w Warszawie.

W 1946 roku Kamiński zaczyna pracę w Katedrze Pedagogiki na Uniwersytecie Łódzkim, gdzie zostaje asystentem Heleny Radlińskiej i pisze doktorat pod kierunkiem Sergiusza Hessena, który stanie się dla niego mentorem i przyjacielem. Jednocześnie jak zawsze włącza się w pracę wychowawczą z młodzieżą, podejmując próbę porozumienia się $\mathrm{z}$ nowymi władzami Polski w sprawie przywrócenia działalności harcerstwa. Zostaje jednym z dwóch wiceprzewodniczących ZHP, członkiem Tymczasowej Naczelnej Rady Harcerskiej i Komisji Ideologicznej Prawa i Przyrzeczenia Harcerskiego. Jednakże już po roku składa dymisję z Naczelnej Rady Harcerskiej, a w 1949 roku zostaje wyrzucony z ZHP

${ }^{23}$ Aleksander Kamiński, Antek Cwaniak. Książka o zuchach, wyd. IV (Warszawa: Harcerskie Biuro Wydawnicze 1947), 5-6.

${ }^{24}$ Tamże, 6. 
z powodów politycznych (w 1950 zostaje usunięty z Uniwersytetu Łódzkiego, podobnie jak Helena Radlińska). Trylogia zuchowa zostaje objęta cenzurą i wycofana. Dopiero w roku 1956 na fali politycznej odwilży, po burzliwym grudniowym zjeździe działaczy harcerskich w Łodzi, odbywającym się pod egidą silnie skomunizowanej Organizacji Harcerskiej ZMP, Kamiński podejmuje jeszcze jedną próbę ratowania harcerstwa. Zgadza się na przyjęcie funkcji przewodniczącego Naczelnej Rady Harcerskiej, bierze udział w negocjowaniu i redagowaniu nowego tekstu przyrzeczenia i prawa harcerskiego, także Obietnicy i Prawa Zucha. Z radością przyjmuje oddolne odradzanie się ruchu zuchowego. Przygotowuje do druku piąte wydanie Książki Wodza Zuchów pod zmienionym tytułem: Książka drużynowego zuchów, ponieważ nowa struktura ruchu znosi "gromady zuchowe” i ich „wodzów”, wprowadzając w zamian „drużyny zuchowe” i „drużynowych”. W treści uwzględnione są już zarówno drużyny chłopców, dziewczynek, jak i drużyny koedukacyjne, choć w podawanych przykładach pozostały pomysły przeznaczone głównie dla chłopców. Zacytujmy Przedmowę do poprawionego i wydanego w 1957 roku drugiego tomu zuchowej trylogii:

Po siedmioletniej przerwie znów odradza się harcerstwo. Trzeba z radością stwierdzić, że zuchy przodują w tej odnowie. Przodują nie tylko dlatego, że dział zuchowy był jednym z tych, który najpierw podniósł głowę. Przodują przede wszystkim dlatego, że wśród ludzi, którzy podjęli pracę zuchową, panuje zapał, harmonia i duża wydajność pracy ${ }^{25}$.

Niestety, już w kwietniu 1958 roku nasilają się represje wobec wielu instruktorów. Ostatecznie po likwidacji prezydium Naczelnej Rady Harcerskiej Kamiński w 1959 roku decyduje się zrezygnować z funkcji jej przewodniczącego. Pozostaje szeregowym członkiem ZHP, żeby nie wywoływać fali odejść ze związku. W tym czasie harcerstwo liczy 600 tysięcy harcerzy, w tym - 125 tysięcy zuchów ${ }^{26}$. Mimo krótkiego czasu aktywnej działalności po 1956 roku Aleksander Kamiński sprawił, że struktury związku odbudowano, wielu przedwojennych instruktorów mogło, choć w coraz trudniejszych warunkach, jednak rozwinąć pracę harcerską i zuchową, kształcić młodych instruktorów ${ }^{27}$. (Mogę o tym zaświadczyć osobiście, mając za sobą doświadczenie zuchowania i drogi harcerskiej aż do zuchmistrza w stopniu harcmistrza, drogi przebywanej od końca lat 50. pod kierunkiem wspaniałych przedwojennych instruktorów). Sam Kamiński od tego momentu odsunął się od czynnej działalności harcerskiej, a jego trylogia zuchowa doczekała się kolejnych wydań dopiero w latach 80 . Sytuacja społeczno-polityczna sprawiła,

25 Kamiński, Książka, 5.

26 Wachowicz, Kamyk, 435.

27 Potwierdzają to między innymi: Janowski, Być dzielnym i Kazimierz Koźniewski, I zawsze krzyż oksydowany... Refleksja nad historia harcerstwa w Polsce 1911-1986 (Kraków: Wydawnictwo Literackie 1990). 
że w późniejszych podręcznikach i materiałach metodycznych adresowanych do kadry ruchu zuchowego, a publikowanych w okresie PRL, autorzy nie wspominali o Kamińskim ani jako o twórcy ruchu, ani autorze głównych koncepcji metodycznych, chociaż w wielu miejscach przywoływali jego pomysły i rozwiązania ${ }^{28}$.

Kamiński, będąc twórcą i przewodnikiem ważnej dziecięcej i młodzieżowej organizacji wychowawczej, znalazł się w PRL na pierwszej linii politycznych nacisków związanych $\mathrm{z}$ dostosowaniem programu ideowego harcerstwa do zmian ustrojowych w Polsce. Po dramatycznych próbach pogodzenia nowych wymogów ideowych $\mathrm{z}$ ideałami ruchu zuchowego i harcerskiego, a także przekonywania środowiska instruktorskiego sceptycznego, a niejednokrotnie zdecydowanie krytycznego wobec tej sprawy Kamiński odchodzi od czynnej służby instruktorskiej. Wierny sobie i swoim ideałom harcerz, instruktor harcerski, pedagog i pisarz, nauczyciel akademicki i uczony, stał się jednak postacią symboliczną dla historii polskiego harcerstwa.

Czas tworzenia ruchu zuchowego to w gruncie rzeczy początek działalności pedagogicznej dorosłego Aleksandra Kamińskiego. Podsumowania, analizy, naukowe opracowanie doświadczeń tego okresu przyjdą później, kiedy Kamiński zajmie się głównie pracą naukową i opracowywaniem biografii wybitnych postaci uznanych przez niego za szczególnie ważne w najnowszej historii Polski, w tym - w historii harcerstwa. Analiza tekstów i działań Kamińskiego pozwala jednak spojrzeć na dzieło ruchu zuchowego jako wyrazistą koncepcję pedagogiczną i konsekwentną pedagogię, stanowiącą znaczącą część polskiego dorobku pedagogicznego. Obraz Kamińskiego jako twórcy ruchu zuchowego najlepiej zarysowuje on sam, pisząc:

Miałem w sobie coś z artysty - mam na myśli „żyłkę twórczości”. Wprawdzie lubiłem się uczyć, lubiłem meblować głowę, ale nie mniej lubiłem ekspresę̨ i eksperymentowanie, pociągały mnie bardzo innowacje zapewniające większą efektywność wychowawczą. Myślę, że właśnie dzięki temu pociągowi ku twórczości, ku eksperymentowaniu zawdzięczam swe sukcesy wychowawcze w kształtowaniu zuchowej gałęzi harcerstwa, opracowaniu metody harcerskiej w nauczaniu i wychowywaniu szkolnym, w ujęciu samorządu młodzieży jako metody wychowawczej ${ }^{29}$.

Nieufność wobec schematycznych metod i ustalonych reguł pracy wychowawczej wzmocnił w Kamińskim kontakt z Januszem Korczakiem. Jak wspominał, Korczak w jednej z rozmów zapytany o to, dlaczego nie napisał podręcznika do wychowania, wyraził wątpliwość, czy taki podręcznik byłby potrzebny i rzeczywiście dobry.

${ }^{28}$ Por. Jerzy Majka, Jak zorganizować drużynę zuchów? (Warszawa: Wydawnictwo Harcerskie 1967); Uczyć się bawić z zuchami. Wybór materiałów do kształcenia drużynowych zuchów (Warszawa: Wydawnictwo Harcerskie 1967).

${ }^{29}$ Aleksander Kamiński, O co mi w pracy wychowawczej szło, za: Janowski, Być dzielnym, 219. 
Prawie stuletnie dzieje ruchu zuchowego wymagałyby szerokiego opracowania, przekraczającego ramy artykułu. Jednakże punktem odniesienia dla zrozumienia historii polskich zuchów jest koncepcja tego ruchu i proces wprowadzania jej w życie przez twórcę tej organizacji - Aleksandra Kamińskiego. Dlatego z bogatego dorobku działalności zuchowej, trwającej nieprzerwanie do dziś, został tu wyodrębniony i przedstawiony etap wyznaczony czasową ramą zaangażowania samego Kamińskiego, jego rolą w powstaniu, prowadzeniu i rozwoju ruchu zuchowego. Jego koncepcja tego ruchu i praktyczna działalność jako zuchmistrza stanowią znaczący wkład w polską myśl pedagogiczną i praktykę wychowawczą.

Ruch zuchowy, podobnie jak całe harcerstwo, nie był ani jedynie, ani głównie metodą wychowawczą. Metody zuchowe, podobnie jak harcerskie miały służyć jasnym celom i ideałom wyznaczonym przez określoną wizję człowieczeństwa. Przywołajmy jeszcze raz Kamińskiego:

Skautowe ćwiczenia i zabawy pomyślane są w ten sposób, aby przede wszystkim rozbudzać w chłopcu najcudowniejsze właściwości człowieka: radość życia, poleganie na sobie i panowanie nad sobą, ciągłą gotowość służby i pomocy innym, poczucie honoru, lojalność, samodzielność i inicjatywę osobistą ${ }^{30}$.

Trzeba w pełni przyznać rację Bogusławowi Śliwerskiemu, określającemu pedagogikę Kamińskiego jako „społeczno-personalistyczną”31. Przejawiła się ona w całej pełni również w ruchu zuchowym.

Wskażmy tylko kilka najważniejszych wątków ukazujących nie tylko specyfikę, ale także niezwykłą aktualność koncepcji „zuchowania” Kamińskiego i związanej z nią pedagogicznej postawy:

- dostrzeżenie znaczenia dziecięcego środowiska rówieśniczego jako środowiska wychowawczego, pozytywnego potencjału wychowywania młodych przez młodych przy założeniu towarzyszenia dorosłych rozumiejących zabawę dzieci i chętnych, by ją inspirować, podsuwać pomysły, służyć pomocą;

- szacunek i miłość do dzieci traktowanych po bratersku i uczonych braterstwa;

- podkreślanie twórczej aktywności instruktora, który tworząc i podsuwając wciąż nowe, atrakcyjne formy zabaw i gier, zachęca również zuchy do przedstawiania własnych pomysłów;

- motywowanie zuchów do doskonalenia własnych umiejętności, do podejmowania kolejnych trudnych zadań w ramach przekraczania kolejnych „progów” przez zdobywanie sprawności i gwiazdek;

- podkreślanie, że ideałem wychowania (szczególnie w organizacji dziecięcej) nie jest „dziecko grzeczne”, ale dziecko dzielne, pokonujące własne słabości

30 Kamiński, Krąg Rady, 11.

31 Bogusław Śliwerski, Współczesne teorie. 
i lęki, ciekawe świata i gotowe go poznawać, radosne, gotowe do wysiłku uczenia się nowych rzeczy, chętne do pomocy innym, wierne podjętym dobrowolnie zobowiązaniom, potrafiące odróżniać dobro od zła;

- docenienie pracy w grupach, przewidującej realizację zadań i wspólnych, i różnych, celowo dostosowanych do możliwości, potrzeb i zainteresowań poszczególnych dzieci;

- przypisywanie decydującej roli w wychowaniu nie systemowi wychowawczemu, ale realizującym go wychowawcom.

Wszystkie wyodrębnione tu cechy ruchu zuchowego mogą, i jak się wydaje, powinny, stale towarzyszyć każdemu, kto decyduje się na rolę pedagoga, świadomie angażując się w proces wychowania.

Streszczenie: Tekst pokazuje początki powstałego w ramach Związku Harcerstwa Polskiego, ruchu zuchowego i rolę, jaką odegrał w powstaniu tego ruchu Aleksander Kamiński wybitny pedagog, instruktor harcerski, autor ważnych dla historii Polski książek o młodych harcerzach - bohaterach powstania warszawskiego 1944 roku.

Analizując przede wszystkim teksty Kamińskiego związane z budowaniem programu ruchu zuchowego, autorka stara się uzasadnić pogląd, iż ruch ten stanowi znaczący element polskiego dorobku pedagogicznego nie tylko w sensie historycznym. Jest on ważny zarówno pod względem klarowności celów, jak i oryginalnych metod i form konsekwentnie służących realizacji tych celów. Ruch zuchowy do dziś korzysta z podstawowych struktur, założeń metodycznych i rozwiązań organizacyjnych stworzonych przez Kamińskiego. Przedstawienie historii ruchu zostało ograniczone do okresu początkowego, do powstania samej koncepcji oraz czasu jej wdrażania zgodnie z założeniami Kamińskiego i pod jego kierunkiem, tzn. do lat 1924-1958.

Słowa kluczowe: harcerstwo, ruch zuchowy, zuchy, organizacja wychowawcza

\section{Bibliografia}

Janowski, Andrzej. Być dzielnym i umieć się różnić. Szkice o Aleksandrze Kamińskim. Warszawa: Wydawnictwo Naukowe PWN, 1992.

Kamiński, Aleksander. Antek Cwaniak. Książka o zuchach, wyd. IV. Warszawa: Harcerskie Biuro Wydawnicze, 1947.

Kamiński, Aleksander. Krag Rady. Katowice: nakładem „Na tropie”, 1937.

Kamiński, Aleksander. Książka drużynowego zuchów, wyd. V. Warszawa: Wydawnictwo Ministerstwa Obrony Narodowej, 1957.

Kieler, Iwona. Dwudziestolecie międzywojenne, t. 24: „Wychowanie w szkole i w domu”. Warszawa: Edipresse Polska SA, 2014.

Koźniewski, Kazimierz, I zawsze krzyż oksydowany... Refleksja nad historiq harcerstwa $w$ Polsce 1911-1986. Kraków: Wydawnictwo Literackie, 1990.

Majka, Jerzy. Jak zorganizować drużynę zuchów? Warszawa: Wydawnictwo Harcerskie, 1967.

Okoń, Wincenty. „Aleksander Kamiński - pedagog praktycznego humanizmu”. W: tegoż, Wizerunki sławnych pedagogów polskich. Warszawa: Wydawnictwa Szkolne i Pedagogiczne, 1993. 
Śliwerski, Bogusław. Wspótczesne teorie i nurty wychowania. Kraków: Oficyna Wydawnicza „Impuls", 1998.

Uczyć się bawić z zuchami. Wybór materiałów do kształcenia drużynowych zuchów. [Art. napisali Wojciech Cesarski et al.]. Warszawa: Wydawnictwo Harcerskie, 1967.

Wachowicz, Barbara. Kamyk na szańcu. Gawęda o druhu Aleksandrze Kamińskim w stulecie urodzin. Warszawa: Oficyna Wydawnicza Rytm, 2002. 